DOI: https://doi.org/10.31933/dijdbm.v2i3

Received: $20^{\text {th }}$ April 2021, Revised: $10^{\text {th }}$ May 2021, Publish: $22^{\text {nd }}$ May 2021

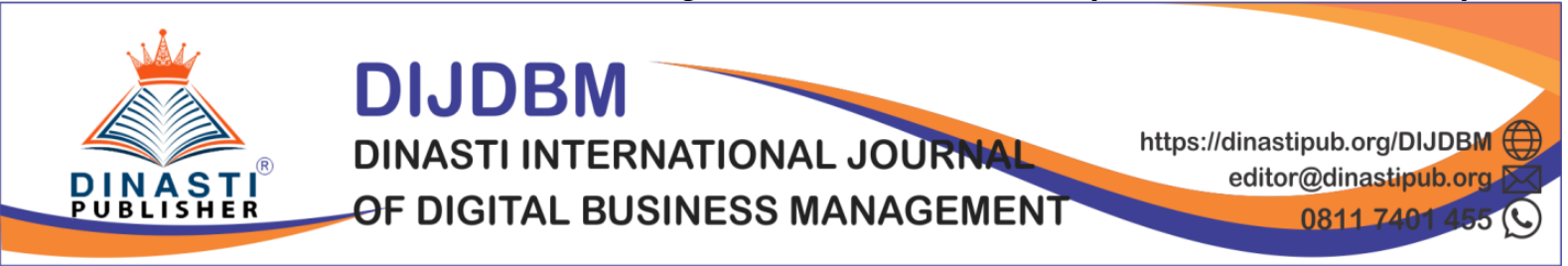

\title{
THE EFFECT OF EMOTIONAL INTELLIGENCE, COMMUNICATION AND TEAMWORK ON EMPLOYEE PERFORMANCE
}

\author{
${ }^{1}$ C. Catur Widayati, ${ }^{2}$ Agus Arijanto, ${ }^{3}$ Purnamawati Hellen Widjaja, ${ }^{4}$ Agustina $T$. \\ Fintura \\ ${ }^{1,2,4}$ Faculty of Economics and Business, Universitas Mercu Buana Jakarta \\ Email: catur.widayati@mercubuana.ac.id / christinewijaya73@yahoo.co.id \\ ${ }^{3}$ Faculty of Economics and Business, Tarumanagara University \\ Email: purnamawatiw@fe.untar.ac.id
}

\section{Corresponding Author: First Author}

Abstract: This study aims to examine and analyze the effects of emotional intelligence, communication, and teamwork on employee performance at PT XYZ. The population in this study was 50 people. The sample used was 50 respondents. The sampling method used saturated samples. Data collection Methods used survey, with the research instrument was a questionnaire. Data analysis method used Structural Equation Model (SEM) with Smart-PLS 3.3.2 analysis tool. The results showed that the emotional intelligence variable had a positive and significant effect on employee performance. Communication had a positive and significant effect on employee performance. Teamwork had a positive and significant effect on employee performance.

Keywords: Emotional Intelligence, Communication, Teamwork, Employee Performance

\section{INTRODUCTION}

Human Resources are the most valuable assets owned by an organization, although currently technology is increasingly advanced and the use of machines continues to increase, HR still plays a role as a driving force for every activity in the organization. The quality of human resources are the strength of an organization where employees provide the best results for every job they do.

In this research, the problems faced by PT. XYZ is the decline of employee performance. This company is professionally running its business as a retailer for export and fashion products in Indonesia. The beginning of the establishment of PT. XYZ is by placing itself in well-known deptstores in Indonesia, currently PT. XYZ have also independently established as a provider of casual branded products in strategic locations and shopping centers throughout Indonesia. The phenomenon occurs is that the decline of employee performance influence on the decline of sales, to support the occurrence of this phenomenon, the authors conducted a pre-survey of 15 employees, Where it can be explained that from several indicators in the pre-survey that have been given, there are indications of problems in employee performance, namely 9 or $60 \%$ of respondents disagree with the indicator of "I can complete the work according to the time determined by the company". Meanwhile, 10 or $67 \%$ of respondents disagree with the indicator of "I am able to complete what is targeted by 
the company". And 11 or $73 \%$ of respondents disagree with the indicator of "I am able to maintain and improve the quality of work". Good performance can support the success of a company. Because good performance increases productivity, so that company goals can be achieved. On the other hand, if employee performance decreases, it will hinder the company from achieving its goals.

The decrease in employee performance is shown in the following table:

Table 1. Sales Recapitulation of PT. XYZ in 2018 - 2019

\begin{tabular}{cccc}
\hline 2018 & Sales & $\begin{array}{c}2019 \\
\text { Month }\end{array}$ & Sales \\
Month & & January & 4,003 \\
\hline January & 4,198 & February & 3,791 \\
February & 3,956 & March & 3,723 \\
March & 3,818 & April & 3,346 \\
April & 3,598 & May & 4,690 \\
May & 4,783 & June & 5,127 \\
June & 5,438 & July & 4,009 \\
July & 4,087 & August & 4,204 \\
August & 4,335 & September & 4,065 \\
September & 4,364 & October & 4,173 \\
October & 4,277 & November & 4,040 \\
November & 4,215 & December & 4,654 \\
December & 4,827 & Total & 49,825 \\
Total & 51,896 &
\end{tabular}

Source: Internal Data of PT. XYZ

Based on the table sales in 2018 amounted to 51,896 while in 2019 amounted to 49,825 , this means that sales in 2019 have decreased compared with sales in 2018. The decline of sales influence on losses for the company which means the company has not maximally achieved its goals. Companies and employees work together to achieve goals, so employees should maintain their performance, because optimal employee performance is one of the assets for the company to achieve its goals.

In addition, there was a decrease in sales caused by a decline in employee performance due to several factors that influenced it, including a decrease in attendance levels. The fairly high level of employee absenteeism occurred at the level of illness, namely the total number with a percentage of $18.2 \%$, for permission $8.5 \%$ and for alpha $11.4 \%$. The level of employee absenteeism that continues to increase can affect on the performance of employees who are considered not optimal, as a result, work that should be completed on time is hampered due to employee absence.

From the results of the pre-survey the researcher found the fact that there are indications of problems from the cause of the decline in employee performance at PT. XYZ, one of the factors that influence employee performance is emotional intelligence, which is 12 or $80 \%$ of respondents disagree with the indicator of "I am able to recognize and feel the emotions that are going on inside". Apart from emotional intelligence, communication is also one of the factors that affect employee performance, where 11 or $73 \%$ of respondents disagree with the indicator of "fellow employees have communicated well". Likewise with 
teamwork, there are 10 or $67 \%$ of respondents disagree with the indicator of "In carrying out my duties I have collaborated with each other".

To make sure the factors that affect on employee performance based on previous research found that employee performance is influenced by emotional intelligence, Yusuf (2018) researches that an employee's emotional intelligence is an important element in determining the results of his work. Without a well-ordered emotional stability, it is likely that all of the individual's activities will be hampered.

Research conducted by Thamrin (2017) states that good and effective communication, both vertically up and down as well as horizontal communication, will also achieve a high level of performance. This is because employees can understand everything that is done on the job. Eva's research results (2018) The first factor that can help an employee improve performance is teamwork. The meaning of the concept of team lies in an expression that describes the emergence of synergy among people who bind themselves in a group called a team.

When solving problems faced in doing work, emotional intelligence is very important for every employee because it will help employees relate to other employees to share information and manage conflicts that arise in carrying out their work tasks, then communication is well established among fellow employees and to superiors it is very important to avoid communication errors that can hinder performance and build solid teamwork, because the work is done not only by one division group but consists of other groups, where each section has its respective roles in an effort to improve employee performance so that it is well maintained and company goals can be achieved.

Based on the background above, the problems in this study are: (1) Does emotional intelligence affect on performance of employees at PT. XYZ?; (2) Does communication affect on performance of employees at PT. XYZ?; (3) Does teamwork affect on organizational communication at PT. XYZ?

While the objectives in conducting this research are: (1) Knowing and analyzing the effect of emotional intelligence on employee performance at PT. XYZ; (2) Knowing and analyzing the influence of communication on employee performance at PT. XYZ; (3) Knowing and analyzing the effect of teamwork on employee performance at PT. XYZ.

\section{LITERATURE REVIEW}

\section{Emotional Intelligence}

Emotional intelligence can play a role as moderating employee work stress. An employee who has good emotional intelligence, is not only able to improve his performance, but also can reduce work stress (Sanjaya, 2012). According to Robbin \& Judge (2015) emotional intelligence is a person's ability to assess emotions in themselves and in others understand the meaning of emotions, and regulate one's emotions regularly. Goleman (2015) suggests that emotional intelligence is a characteristic of people who stand out in real life. Emotional intelligence has the ability to motivate themselves, withstand frustration, control impulses, regulate moods so that the burden of stress does not paralyze their thinking ability.

From some of the definitions above, it can be concluded that emotional intelligence is a person's ability to recognize himself and others and to understand and regulate emotions in himself and others in order to create a good and prosperous relationship with himself and others. 


\section{Communication}

According to Mulyana \& Rahmat (2009), communication is a process in which two or more people form or exchange information among one another, which in turn results in deep mutual understanding, through various channels that affect on each other. According to Bangun (2012), communication is the process of conveying information from the sender to the recipient of the message effectively. According to Mangkunegara (2013), argues that communication is an activity that causes other people to interpret an idea, especially what is meant by the conversation or writer.

It can be concluded that communication is a very important tool for conveying or receiving information to or other parties.

\section{Teamwork}

According to Sopiah (2008) stated that a work team is a team whose individual efforts produce a performance that is greater than the amount of individual input. Sinambela (2017) revealed that team work is a group of employees who do a job assigned by the leader to them. The implementation of this work promotes togetherness, mutual trust and support. With good group performance will optimize group performance and provide satisfaction to their superiors.

In addition, Robbins and Judge (2017) revealed that team work is a group that has individual efforts that result in greater performance than the number of individual inputs. It can be concluded that teamwork produces better performance than individual performance in an organization or company.

\section{Employee performance}

According to Hasibuan (2012), performance is a result of work achieved by a person in carrying out the tasks assigned to him based on skills, experience, and seriousness and time. And according to Sudaryono (2017), performance is the result that a person achieves according to the size that applies to the job concerned. A person's performance can be seen through his activities in carrying out his daily work. This activity describes how he tries to achieve the goals that have been set.

Meanwhile, according to Priansa (2018), performance is the result of work achieved by employees in developing tasks and jobs originating from the organization. From some of the opinions above, it can be concluded that employee performance is work performance or work results, both quality and quantity achieved by human resources in carrying out their work tasks in accordance with the responsibilities assigned to them.

\section{Hypothesis Development}

a. The Effect of Emotional Intelligence on Employee Performance

Goleman (2015) suggested that emotional intelligence is a characteristic of people who stand out in real life. Emotional intelligence has the ability to motivate themselves, withstand frustration, control impulses, regulate moods so that the burden of stress does not paralyze their thinking ability.

Research conducted by Desy and Achmad (2018), Yusuf and Lisa (2018) and C. Widayati (2016) found that there is a positive effect of emotional intelligence on employee performance, employees who have high emotional intelligence tend to produce high performance, and on the other hand, employees who have low emotional intelligence tend to 
produce low performance. Based on the above statement, the following hypothesis can be formulated:

H1: Emotional intelligence has a positive effect on employee performance

\section{b. The Effect of Communication on Employee Performance}

According to Bangun (2015), communication is the process of conveying information from the sender to the recipient of the message effectively. It can be concluded that communication is a very important tool for conveying or receiving information to other parties. From the research results of Thamrin (2017), Hamiruddin, et al (2019) and Puryatini and Sariyathi (2017), communication has a positive and significant effect on employee performance. This illustrates that employees with good and effective communication, both vertically up and down as well as horizontal communication, will also achieve high performance. This is because employees can understand everything that is done on the job. Based on the above statement, the following hypothesis can be formulated:

H2: Communication has a positive effect on employee performance

c. The Effect of Teamwork on Employee Performance

Sinambela (2017) revealed that team work is a group of employees who do a job assigned by the leader to them. The implementation of this work promotes togetherness, mutual trust and support. With group performance and giving satisfaction to their superiors. Research conducted by Andi, et al. (2017), Eva and Boge (2017) and Wahyuddin, et al. (2017) that the variable teamwork has an effect on employee performance. Based on the above statement, the following hypothesis can be formulated:

H3: Teamwork has a positive effect on employee performance

\section{RESEARCH METHODS}

The research process begins with the activity of identifying the problem in the place that will be used as the research location, the formulation of the identified problems, the collection of theoretical bases that strengthen the foundation in the variables, so that the statistical testing techniques used are determined. The research object is PT. XYZ located in North Jakarta. The research time began when the researcher made initial observations that distributed pre-research questionnaires, namely November 2018 and this research was completed during the field research in July 2019.

The research design used in this research is causal research, namely a causal relationship. So there are independent and dependent variables (Sugiyono, 2013). While causality analyzes the effect of the independent variables, namely emotional intelligence, communication and teamwork on the dependent variable, namely employee performance. In this case the study aims to determine the effect of emotional intelligence, communication and teamwork on employee performance at PT. XYZ.

\section{Population and Sample}

The population in this study were employees who worked at PT. XYZ, totaling 50 employees. The sample of this research is part of the population taken as a data source and can represent the entire population. Samples taken from this population must be truly representative. If the sample is not representative, it will be difficult to make conclusions from what is being studied. The sampling technique used in this study is a saturated sampling technique in which the sampling process from the population makes all members of the 
population used as the research sample. Then the number of samples used in this study were 50 respondents.

\section{RESULTS AND DISCUSSION \\ Evaluate the Measurement (outer) Model \\ Convergent Validity}

Table 2.The results of the Convergent Validity test

\begin{tabular}{|c|c|c|c|}
\hline Variable & Indicator & Outer Loading & Information \\
\hline \multirow{8}{*}{ Emotional Intelligence } & NUMBER 1 & 0.938 & Valid \\
\hline & 2ND & 0880 & Valid \\
\hline & TO 4 & 0.653 & Valid \\
\hline & KE5 & 0.924 & Valid \\
\hline & KE6 & 0.913 & Valid \\
\hline & $8 \mathrm{TH}$ & 0.918 & Valid \\
\hline & KE9 & 0.883 & Valid \\
\hline & KE10 & 0.721 & Valid \\
\hline \multirow{8}{*}{ Communication } & $\mathrm{K} 2$ & 0.955 & Valid \\
\hline & K3 & 0.949 & Valid \\
\hline & K4 & 0864 & Valid \\
\hline & K5 & 0.975 & Valid \\
\hline & K6 & 0.530 & Valid \\
\hline & K7 & 0.952 & Valid \\
\hline & K8 & 0.973 & Valid \\
\hline & K9 & 0.970 & Valid \\
\hline \multirow{5}{*}{ Teamwork } & T1 & 0.912 & Valid \\
\hline & $\mathrm{T} 2$ & 0.980 & Valid \\
\hline & $\mathrm{T} 3$ & 0.972 & Valid \\
\hline & T5 & 0.544 & Valid \\
\hline & T6 & 0.972 & Valid \\
\hline \multirow{10}{*}{ Employee performance } & KK1 & 0.964 & Valid \\
\hline & KK2 & 0.960 & Valid \\
\hline & KK3 & 0.910 & Valid \\
\hline & KK4 & 0.956 & Valid \\
\hline & KK5 & 0.629 & Valid \\
\hline & KK6 & 0.971 & Valid \\
\hline & KK8 & 0.506 & Valid \\
\hline & KK9 & 0.791 & Valid \\
\hline & KK10 & 0.902 & Valid \\
\hline & KK11 & 0.582 & Valid \\
\hline
\end{tabular}

Source: PLS Output (2019) 


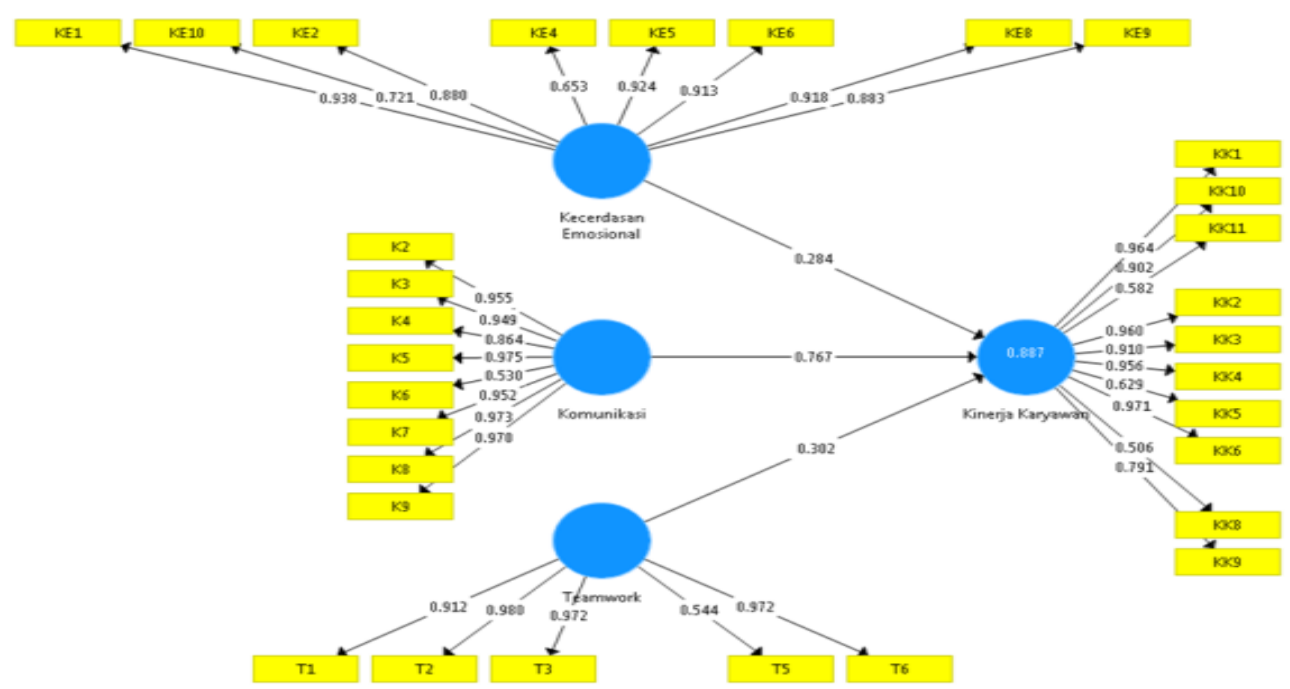

Figure 1. Results of the PLS Algorithm Source: PLS Output, 2019

The results of the modification of the convergent validity test in Figures and Tables, it can be seen that all indicators have met the convergent validity because they have a loading factor value above 0.70 .

\section{Discriminant Validity}

Discriminant validity testing, namely a reflective indicator, can be seen in the cross loading between the indicator and the construct. An indicator can be declared valid if it has the highest loading factor for the intended construct compared to the loading factor for other constructs.

Table 3.Test Results for Discriminant Validity (Cross loadings)

\begin{tabular}{ccccc}
\hline & $\begin{array}{c}\text { Emotional } \\
\text { Intelligence }\end{array}$ & $\begin{array}{c}\text { Communicati } \\
\text { on }\end{array}$ & Teamwork & $\begin{array}{c}\text { Employee } \\
\text { performance }\end{array}$ \\
\hline NUMBER & 0.938 & 0861 & 0.748 & 0.926 \\
1 & 0880 & 0.765 & 0.543 & 0.742 \\
2ND & 0.653 & 0.574 & 0.577 & 0.632 \\
TO 4 & 0.924 & 0.905 & 0.763 & 0849 \\
KE5 & 0.913 & 0.898 & 0.684 & 0841 \\
KE6 & 0.918 & 0.966 & 0.596 & 0.825 \\
8TH & 0.883 & 0.728 & 0.752 & 0.706 \\
KE9 & 0.721 & 0.573 & 0.704 & 0.536 \\
KE10 & 0.924 & 0.955 & 0.745 & 0.903 \\
K2 & 0.900 & 0.949 & 0.699 & 0880 \\
K3 & 0.788 & 0864 & 0.547 & 0750 \\
K4 & 0.918 & 0.975 & 0.680 & 0.958 \\
K5 & 0.465 & 0.530 & 0.434 & 0.413 \\
K6 & 0.913 & 0.952 & 0.505 & 0.937 \\
K7 & 0.926 & 0.973 & 0.518 & 0891 \\
K8 & 0.927 & 0.970 & 0.506 & 0.943 \\
K9 & 0.571 & 0.626 & 0.912 & 0.704 \\
\hline T1 & & & &
\end{tabular}




\begin{tabular}{ccccc} 
T2 & 0.633 & 0.752 & 0.980 & 0.652 \\
T3 & 0.563 & 0.680 & 0.972 & 0780 \\
T5 & 0.509 & 0.514 & 0.544 & 0.464 \\
T6 & 0.709 & 0.527 & 0.972 & 0.727 \\
\hline KK1 & 0.898 & 0.932 & 0.789 & 0.964 \\
KK2 & 0871 & 0.934 & 0.597 & 0.960 \\
KK3 & 0.853 & 0817 & 0.520 & 0.910 \\
KK4 & 0.877 & 0.929 & 0.522 & 0.956 \\
KK5 & 0.525 & 0.549 & 0.581 & 0.629 \\
KK6 & 0.883 & 0.943 & 0.783 & 0.971 \\
KK8 & 0.416 & 0.487 & 0.430 & 0.506 \\
KK9 & 0.734 & 0.682 & 0.547 & 0.791 \\
KK10 & 0811 & 0832 & 0.632 & 0.902 \\
KK11 & 0.425 & 0.446 & 0.532 & 0.582 \\
\hline
\end{tabular}

Source: PLS Output, 2019

From Table 3, it can be seen that the correlation of the emotional intelligence construct with its indicators (KE1 is $0.938, \mathrm{KE} 2$ is 0.880 , KE4 is 0.653 , KE5 is 0.924 , KE6 is 0.913, KE8 is 0.918 , KE9 is 0.883 , and KE10 is 0.721 ) are higher than the indicator correlation. emotional intelligence with other constructs, then the correlation of the communication construct with its indicators ( $\mathrm{K} 2$ is $0.955, \mathrm{~K} 3$ is $0.949, \mathrm{~K} 4$ is $0.864, \mathrm{~K} 5$ is $0.975, \mathrm{~K} 6$ is $0.530, \mathrm{~K} 7$ is 0.952 , $\mathrm{K} 8$ is 0.973 , and $\mathrm{K} 9$ is 0.970 ) this means the indicators higher than the correlation of communication indicators with other constructs, then the correlation of the teamwork construct with the indicators ( $\mathrm{T} 1$ is 0.912 , T2 is 0.980 , T3 is 0.972 , T5 is 0.544 , and T6 is 0.972) this means that the indicator is higher than the correlation of the teamwork indicator with other constructs, as well as the correlation between the employee performance construct and the indicators (KK1 is $0.964, \mathrm{KK} 2$ is $0.960, \mathrm{KK} 3$ is $0.910, \mathrm{KK} 4$ is $0.956, \mathrm{KK} 5$ is 0.629 , KK6 is 0.971 , KK8 of 0.506 , KK9 of 0.791 , KK10 of 0.902, and KK11 of 0.582) higher than the correlation of employee performance indicators with other constructs.

Another method for seeing discriminant validity is by looking at the square root of average variance extracted (AVE) value of each construct with the correlation between constructs and other constructs in the model, so it can be said to have good discriminant validity.

Table 4. AVE Test Results

\begin{tabular}{lc}
\hline \multicolumn{1}{c}{ Variable } & AVE \\
\hline Emotional Intelligence & 0.711 \\
Employee performance & 0.697 \\
Communication & 0.823 \\
Teamwork & 0.796 \\
\hline
\end{tabular}

Source: PLS Output, 2019

Table 5.Test Results for Discriminant Validity (Fornell Lacker Criterium)

\begin{tabular}{|c|c|c|c|c|}
\hline & $\begin{array}{l}\text { Emotional } \\
\text { Intelligence }\end{array}$ & $\begin{array}{l}\text { Employee } \\
\text { performanc } \\
\mathrm{e}\end{array}$ & $\begin{array}{c}\text { Communicat } \\
\text { ion }\end{array}$ & Teamwork \\
\hline $\begin{array}{l}\text { Emotional } \\
\text { Intelligence }\end{array}$ & 0.843 & & & \\
\hline $\begin{array}{l}\text { Employee } \\
\text { performance }\end{array}$ & 0.809 & 0.835 & & \\
\hline
\end{tabular}




\begin{tabular}{lrrrr}
\hline Communication & 0.747 & 0.740 & 0.907 & \\
Teamwork & 0.736 & 0.753 & 0.788 & 0.892 \\
\hline
\end{tabular}

Source: PLS Output, 2019

From Table 5, it can be concluded that the square root of the average variance extracted $(\sqrt{A V E})$ for each construct is greater than the correlation between one construct and the other constructs in the model. The AVE value is based on the table above, it can be concluded that the constructs in the estimated model meet the criteria for discriminant validity.

Table 6. Composite Reliability and Cronbach's Alpha

\begin{tabular}{lccc}
\hline \multicolumn{1}{c}{ Variable } & $\begin{array}{c}\text { Cronbach } \\
\text { Alpha's }\end{array}$ & $\begin{array}{c}\text { Composite } \\
\text { Reliability }\end{array}$ & Information \\
\hline Emotional Intelligence & 0.937 & 0.950 & Reliable \\
Employee performance & 0.946 & 0.957 & Reliable \\
Communication & 0.966 & 0.973 & Reliable \\
Teamwork & 0.929 & 0.949 & Reliable \\
\hline
\end{tabular}

Source: PLS Output, 2019

Based on Table 6, it can be seen that the test results of composite reliability and Cronbach's alpha show a satisfactory value, because all latent variables have a value of composite reliability and Cronbach's alpha $\geq 0.70$. This means that all latent variables are said to be reliable.

\section{Structural Model Testing or Hypothesis Testing (Inner Model)}

\section{R-square value}

Table 7. ValueR ${ }^{2}$ Endogenous Variables

\begin{tabular}{lc}
\hline \multicolumn{1}{c}{ Endogenous Variables } & R-square \\
\hline Employee performance & 0.887 \\
\hline Source: PLS Output, 2019 &
\end{tabular}

In Table 7 above, it can be explained that the structural model indicates that the model on the employee performance variable can be said to be strong because it has a value above 0.67. Model of the influence of the independent latent variables (emotional intelligence, communication, and teamwork) on employee performance gives an R-square value of 0.887 which can be interpreted that the variability of the employee performance construct which can be explained by the variability of the constructs of emotional intelligence, communication, and teamwork amounted to $88.7 \%$ while $11.3 \%$ was explained by other variables outside the study.

\section{Goodness of Fit Model}

Testing the Goodness of Fit structural model on the inner model uses the predictiverelevance value $\left(\mathrm{Q}^{2}\right)$. The $\mathrm{Q}$-square value is greater than 0 (zero), indicating that the model 
has a predictive relevance value. The $\mathrm{R}$-square value of each endogenous variable in this study can be seen in the following calculations:

The predictive relevance value is obtained by the formula:

$Q^{2}=1-(1-R 1)\left(1-R_{p}\right)$

$Q^{2}=1-(1-0.887)$

$Q^{2}=1-(0.113)$

$Q^{2}=0.8870$

The results of the above calculations show the predictive-relevance value of 0.8870 , which is greater than 0 (zero). It means that $88.70 \%$ employee performance (dependent variable) is described by the independent variable used. Thus the model is said to be worthy of having a relevant predictive value.

\section{Hypothesis Testing (Estimated Path Coefficient)}

The estimated values for the path relationships in the structural model must be significant. The significance value of this hypothesis can be obtained by the boostrapping procedure. Seeing the significance of the hypothesis by looking at the value of the parameter coefficient and the value of the T-statistic significance in the algorithm boostrapping report. To find out whether it is significant or not, it is seen from the T-table at alpha $0.05(5 \%)=$ 1.96, then the T-table is compared with the T-count (T-statistic).

Table 8. Hypothesis Testing Results

\begin{tabular}{lccccc}
\hline & $\begin{array}{c}\text { Original } \\
\text { Sample }\end{array}$ & $\begin{array}{c}\text { Standard } \\
\text { Deviation }\end{array}$ & $\begin{array}{c}\text { T- } \\
\text { Statistics }\end{array}$ & $\begin{array}{c}\text { P } \\
\text { Values }\end{array}$ & Information \\
\hline $\begin{array}{l}\text { Emotional Intelligence } \rightarrow \\
\text { Employee performance }\end{array}$ & 0.284 & 0.124 & 2,289 & 0.001 & $\begin{array}{c}\text { Positive - } \\
\text { Significant } \\
\begin{array}{l}\text { Communication } \rightarrow \text { Employee } \\
\text { performance }\end{array}\end{array}$ \\
$\begin{array}{l}\text { Teamwork } \rightarrow \text { Employee } \\
\text { performance }\end{array}$ & 0.767 & 0.187 & 4,105 & 0,000 & $\begin{array}{c}\text { Positive - } \\
\text { Significant } \\
\text { Positive - } \\
\text { Significant }\end{array}$ \\
\hline
\end{tabular}

Source: PLS Output, 2019 


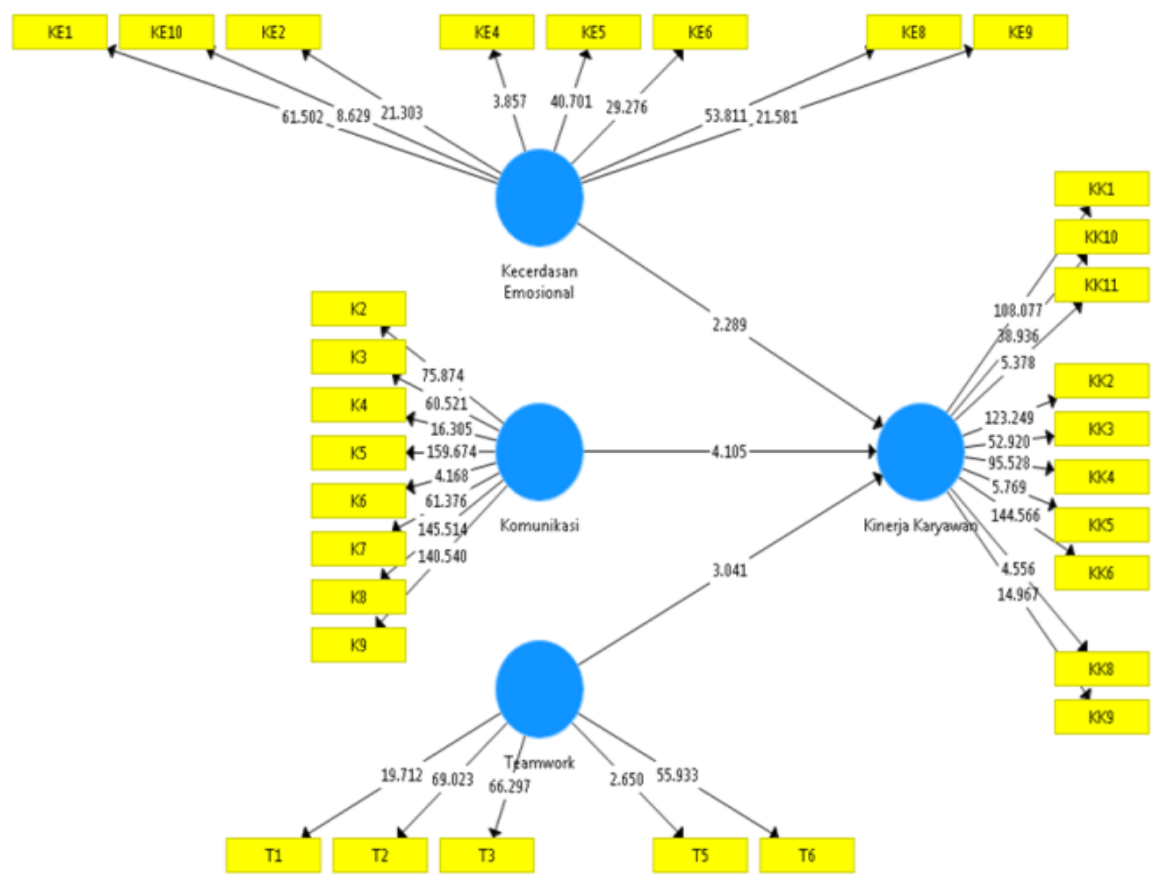

Figure 2. Boostrapping Test Results

Source: PLS Output, 2019

\section{Discussion of Research Results}

\section{The Effect of Emotional Intelligence on Employee Performance}

Based on the hypothesis test in this study, the T-statistic value was 2.289 , the original sample value was 0.284 , and the $\mathrm{P}$ Values value is 0.001 . The T-statistic value is greater than the T-table value of 1.96, the original sample value shows a positive value, and the $\mathrm{P}$ value shows less than 0.05 , these results indicate that emotional intelligence has a positive and significant effect on employee performance.

Based on the results of the processed data, the results show that there is a relationship between emotional intelligence and employee performance. In relation to the achievement of high employee performance, it needs to be based on several approaches, one of which is the psychological approach of the employees themselves and the organization. Psychological and organizational approaches to performance include approaches to personality and emotional intelligence from human resources in the company. Where, self-awareness will affect on performance because determining the goals to be achieved requires knowledge of oneself. Goleman (2015) suggested that emotional intelligence is a characteristic of people who stand out in real life. This research supports research conducted by Desy and Achmad (2018) where in their research it is revealed that there is a positive effect of emotional intelligence on employee performance which shows that employees who have high emotional intelligence tend to produce high performance, and vice versa employees who have intelligence. low emotional levels tend to result in low performance.

\section{The Effect of Communication on Employee Performance}

Based on the hypothesis testing in this study, the T-statistic value was 4.105 , the original sample value was 0.767 , and the $\mathrm{P}$ Values value is 0,000 . The T-statistic value is 
greater than the T-table value of 1.96, the original sample value shows a positive value, and the $\mathrm{P}$ value shows less than 0.05 , these results indicate that communication has a positive and significant effect on employee performance.

The results of this study prove that communication has a direct positive effect on the performance of employees of PT. XYZ. John and Lay (2004) stated that in managing an organization, it is necessary to take action from the leadership to make policies in communicating with outsiders or external to the organization. Meanwhile, Novita et al. (2002) found that effective communication between superiors and subordinates is very influential on employee job satisfaction so that performance will be more optimal. Communication fosters motivation by explaining to employees what to do, how they are doing well and what to do to improve performance if it is below standard.

Based on the results of the study, the highest average item value answered by the respondents was horizontal communication related to communication between colleagues. The employees of PT. XYZ feels comfortable communicating with fellow division colleagues. Employees can provide mutual support at work and are able to reconcile disputes that occur between coworkers. So that this is considered by employees as one of the important factors that encourage them to increase their productivity and performance.

The results of this study support the research conducted by Thamrin (2017) which stated that communication has a positive and significant effect on employee performance. This illustrates that employees with good and effective communication, both vertically up and down as well as horizontal communication, will also achieve high performance. This is because employees can understand everything that is done on the job.

\section{The Effect of Teamwork on Employee Performance}

Based on the hypothesis testing in this study, the T-statistic value was 3.041, the original sample value was 0.302 , and the $\mathrm{P}$ Values value is 0,000 . The T-statistic value is greater than the T-table value of 1.96, the original sample value shows a positive value, and the $\mathrm{P}$ value shows less than 0.05 , these results indicate that teamwork has a positive and significant effect on employee performance.

Teamwork has an important role in achieving company performance because if good teamwork is established and is able to complete each task and work program in a timely and effective manner, it will certainly create good work results. Every employee must always prioritize common interests so that they can provide maximum contribution between superiors and subordinates and fellow colleagues. Good teamwork, of course, must be maintained in a company because with good teamwork, every workload faced will be resolved on time and effectively according to the objectives that have been planned. Good teamwork will create and improve employee performance, therefore teamwork is very important for the progress of a company. Teamwork really helps the work process of employees at PT. XYZ are becoming faster and more focused, because the implementation of teamwork that is getting better will increasingly have an effect on improving employee performance. For the application of teamwork in the dimension of a strong team as a work magnet, it is basically good, the indicators are that employees are able to work together, are creative and have good work initiatives. But the teamwork dimension that still really needs to be developed is the priority of attention and action where employees will be increasingly able to work consistently both on assigned tasks and direct assignments from the leadership, because sometimes employees find it difficult to maximize work, especially when there is an assignment from the leader with different tasks. This researcher is in line with Andi, et al. 
(2017) where the teamwork, communication and work discipline variables that have a dominant effect on employee performance is teamwork.

\section{CONCLUSION AND SUGGESTION Conclusion}

This study tries to analyze the variables related with emotional intelligence, communication, teamwork, and employee performance. The results of this study were obtained from employees of PT XYZ. The following conclusions can be drawn:

1) Emotional intelligence has a significant positive effect on employee performance at PT. $\mathrm{XYZ}$. This means that employees who have high emotional intelligence tend to produce high performance, and vice versa.

2) Communication has a significant positive effect on employee performance at PT. XYZ. This means that employees with good and effective communication, both vertically up and down as well as horizontal communication, will also achieve high performance.

3) Teamwork has a significant positive effect on employee performance at PT. XYZ. This means that the higher the teamwork level in organization, the higher the level of employee performance that will improve.

\section{Suggestion}

Based on the conclusions, several suggestions can be put into consideration for PT. XYZ as well as for further researchers:

1) The company is expected to be able to determine the needs to trigger employees responsibilities of their duties. Individual emotional intelligence must be considered so that good social competence can be created and employee emotional intelligence can be maintained and continues to increase performance.

2) The company is expected to continue to maintain and improve good communication with employees, which can be done by the leadership by enforcing every rule to all employees so that employees do not feel that the leadership discriminates against their employees.

3) The company is expected to evaluate the ability to cooperate with fellow employees so that employees know how far they have been. Then the company also needs to form a management team that is able to carry out job designs, decision-making processes and problem solving related to the cohesiveness of employees in working together so that their performance is also increased.

4) Companies are expected to always monitor the accuracy and precision of employees in completing work, such as going down directly when employees finish work.

Suggestions for the next researcher, who will conduct on the research in the same field and use this thesis as a reference, it is necessary to re-examine it because it does not rule out that there are statements that are not appropriate, because I as a writer feel that there are still many shortcomings and limitations in completing the thesis. We recommend that the next researchers, re-develop other variables that affect employee performance such as job satisfaction, leadership, workload, and work environment that have been done by previous experts and researchers.

\section{REFERENCES}

Afandi, P. (2016). Concept \& Indicator Human Resources Management for Management Research. Yogyakarta: Deepublish.

Bangun, W. (2015). Manajemen Sumber Daya Manusia. Jakarta: Erlangga. 
Black, J., Kim, K., Rhee, S., Wang, K., Sakchutchawan, S. (2018). Self Efficacy and emotional intelligence: Influencing team cohesion team performance. Team Performance Management: An International Journal, 25 (1/2), 100-119.

Dessler, G. (2015). Manajemen Sumber Daya Manusia. Jakarta: Salemba Empat.

Dhani. P \& Sharma. T. (2017). Effect of Emotional Intelligence on Job Performance of IT employees: A gender study Procedia Computer Science 122, 180185.

Efendi, Angelia, V., \& Sutanto, E.M. (2013). Pengaruh Faktor-faktor Kecerdasan Emosional Pemimpin Terhadap Komitmen Organisasional Karyawan Di Universitas Kristen Petra, 1(1).

Febrial, E. \& Herminingsih, A. (2020). The Effect Of Organizational Communication And Job Satisfaction On Employee Engagement And Employee Performance At PT. Abyor International. Dinasti International Journal of Education Management And Social Science, 1(4), 479-489. https://doi.org/10.31933/dijemss.v1i4.216

Erfiana, Musriha, E., \& Noviandri, I. (2018). Pengaruh Teamwork, Beban Kerja Dan Komunikasi terhadap Kinerja Karyawan PT. Bumi Wahyu Kencana di Surabaya Jurnal Manajemen Branchmarck. 4(3).

Ferdinand, A. (2014). Metode Penelitian Manajemen BP Universitas Diponegoro. Semarang.

Ghozali, I. (2014). Structural Equation Modeling, Metode Alternatif dengan Partial Least Square (PLS). Edisi 4 Semarang: Badan Penerbit Universitas Diponegoro.

Goleman, D. (2015). Emotional Intelligence: Kecerdasan emosional mengapa EL lebih penting daripada IQ. Jakarta: PT. Gramedia Pustaka Utama.

Moeheriono. (2010). Pengukuran Kinerja Berbasis Kompetensi. Bogor: Penerbit Ghalia Indonesia.

Muhammad, A. (2017). Komunikasi Organisasi, Edisi III. Jakarta: Bumi Aksara.

Mulyana, D. \& Jalaludin, R. (2009). Komunikasi Antarbudaya. Bandung: Remaja Rosdakarya.

Noor, M.T. (2017). Pengaruh Pelatihan, Komunikasi dan Kecerdasan Emosional terhadap Kinerja Pegawai (Studi Kasus Dinas Kependudukan Dan Pencatatan Sipil Kabupaten Kotawaringin Timur). E-Jurnal Profit (Jurnal Penerapan Ilmu Manajemen dan Kewirausahaan). 2(2), 53-62.

Prasetyo, A.C., Sutopo., \& Noviandari, I. (2017). Pengaruh Tim Kerja, Komunikasi dan Disiplin Kerja terhadap Kinerja Karyawan pada PT. Momen Global Internasional Surabaya. Jurnal Manajemen Branchmark, 3(3).

Priansa, D.J. (2018). Perencanaan \& Pengembangan SDM. Bandung: Alfabeta.

Priansa, D.J. (2017). Manajemen Kinerja Kepegawaian. Bandung: Alfabeta.

Putri, L.D.P. \& Sariyathi, N.K. (2017). Pengaruh Gaya Kepemimpinan Transformasional, Kerjasama Tim, dan Komunikasi Terhadap Kinerja Karyawan Warung Mina Cabang Renon. E-Jurnal Manajemen Unud. 6(6).

Robbins, S.P., \& Judge, T.A. (2017). Organizational Behaviour, Edisi 13, Jilid 1, Salemba Empat, Jakarta.

Robbins, S.P., \& Judge, T.A. (2015). Perilaku Organisasi. Jakarta: Salemba Empat.

Robbins, S.P., \& Judge, T.A. (2014). Perilaku Organisasi. Edisi ke 16. Salemba Empat. Jakarta.

Robbins, S.P., \& Coulter, M. (2010). Manajemen Edisi Kesepuluh Jakarta: penerbit Erlangga. 
Robbins, S.P., \& Judge, T.A. (2008). Perilaku Organisasi. Jakarta. Salemba Empat.

Sanjaya, W. (2012). Strategi Pembelajaran Berorientasi Standar Proses Pendidikan. Jakarta: Kencana Prenada Media Group.

Sarwono. S.W. (2011). Psikologi Remaja. Jakarta: PT. Raja Grafindo Persada.

Setyorini, D. \& Syahlani, A. (2018). Pengaruh Kecerdasan Emosional Terhadap Kinerja Karyawan Hotel Pitagiri, Pekanbaru. Jurnal AKRAB JUARA. 3(4).

Shonubi, A.O \& Akinaro, A.A. (2016). The Impact Of Effective Communication On Organizational Performance. The International Journal of Social and Humanities Invention, 3(3), 1904-1914.

Silvani, E. \& Lawasi, B.,T. (2017). Pengaruh Komunuikasi, Motivasi, Dan Kerjasama Tim terhadap peningkatan Kinerja Karyawan. Jurnal Manajemen dan Kewirausahaan Universitas Merdeka Malang. 5(1).

Sinambela, P.L. (2017). Manajemen Sumber Daya Manusia. Jakarta: PT. Bumi Aksara.

Soelton, M., Pebriani, P., Umar, M., Triwulan, J., \& Wilantara, J. (2018). How Transformational Leadership, Communication, And Workload On The Employee Performance Affect Shoes Industries. South East Asia Journal of Contemporary Business, Economics and Law, 17 (5).

Sofyani, H. (2016). Modul Praktik Partial Least Square (PLS): Untuk Penelitian Akuntansi. Universitas Muhammadiyah Yogyakarta.

Sopiah. (2008). Perilaku Organisasional dan Operasional Management, Andi Offset. Yogyakarta.

Sudaryono. (2017). Metodologi Penelitian. Jakarta: PT. Raja Grafindo Persada.

Sugiyono. (2013). Metode Penelitian Pendidikan Pendekatan Kuantitatif, Kualitatif, dan $R \& D$. Bandung: Alfabeta.

Syamsuddinnor. (2014). Pengaruh Pemberian Pemberian Insentif Dan Disiplin Kerja Terhadap Kinerja Karyawan Pada PT Ben Line Agencies (BLA) Banjar Masin. Jurnal Socioscientia, 6 (1), 1-44.

Totalia, S. A., \& Hindrayani, A. (2013). SPSS \& DEA "Implementasi pada Bidang Pendidikan dan Ekonomi".

Utomo, B. (2019). Analisis Pengaruh Kompetensi Komunikasi, Kecerdasan Emosional Dan Budaya Organisasi Terhadap Kinerja Karyawan (Studi Pada PT. Bangun Jaya Alam Permai I, Di Kotawaringin Barat). Jurnal Ilmu Ekonomi, Manajemen, dan Akuntansi. 8(1), 10-16.

Widayati, Catur. (2016). Pengaruh Kecerdasan Emosional, Tingkat Pendidikan Dan Karir Terhadap Kinerja Karyawan (Studi kasus pada Sales Marketing PT. Astra International Daihatsu Cabang Tangerang). Jurnal Ekonomi, 21(2), 213-231.

Wirawan. (2015). Manajemen Sumber Daya Manusia Indonesia Teori, Psikologi, Hukum Ketenagakerjaan, Aplikasi, dan Penelitian: Aplikasi Dalam Organisasi Bisnis, Pemerintahan Dan Pendidikan. Jakarta: Raja Grafindo Persada.

Yusuf Ardiansyah, Lisa Harry Sulistiyowati. (2018). Pengaruh Kompetensi dan Kecerdasan Emosional Terhadap Kinerja Pegawai Dinas Pendidikan dan Kebudayaan Kabupaten Kuningan. Jurnal Inspirasi Bisnis dan Manajemen 2 (1), 91-100. 